noticed apparently, till I had gained sufficiently on M'Guire to make him hear. I then coo-eed once; he turned and came back to meet me; but at the sound of my coo-ee the fish started off seawards out of sight (under water), and doubled again in-shore, but so rapidly as to leave both outward and inward "ridge" on the water distinctly visible at once, like a wide $\mathrm{V}$ with quite a sharp corner. It gave me the idea of two fishes, the one darting outwards, the other crossing its track inward at the same moment.

"Not knowing where it might show up next, but satisfied that it had come in-shore again, I tried by pointing seaward to direct M'Guire's attention that way.

"Just as I met him the fish again came to the surface, showing gradually more and more of his length, till, when he was almost at rest, and all apparently was in view, I estimated the length to be 60 feet, straight and taper, like a long spar, with the butt-end, his head and shoulders, showing well above the surface.

"I can only describe the head as like the end of a log, bluff, about two feet diameter; on the back we noticed, showing very distinctly above water, several square-topped fins."

I here make an exact tracing from Mr. Brown's letter of his sketch :-

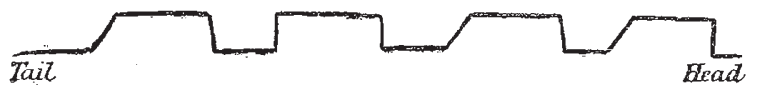

"It was now getting rather too dark to see details distinctly. The fish proceeded towards Lockville, and I turned homeward. M'Guire said he would go on to Lockville jetty and look out for him there.

"Whether he saw him again I know not, but M'Mullan, the frsherman, told me next morning that he had seen it about fifty yards from that jetty, and it looked to him about twenty feet long. So it did to me while in motion; only when at rest for a moment did its whole length show up sufficiently. What its propelling power was I cannot say from observation; I saw no lateral fins and no fish-tail.

"When it started away at the sound of my voice, it was with the rapid movement of a pilie or sword-fish, and yet the thick, bluff head had but little resemblance to a snake's.

"There was an tunsulal abundance of fish close in-shore the same afternoon, yet when I saw the stranger there were certainly no fish of which it could be in pursuit."

Since the year 1848 , when the captain and officers of a British man-of-war gave evidence that they passed within Ioo yards of a snake which they estimated to be 60 feet in length above water with probably 40 feet beneath. I do not know of any more clear account than the above. Many independent accounts of the existence of marine monsters have been placed on record, and it seens mere folly to treat these repeated reports with ridicule.

I trust that your readers will no longer doubt that "the age of incredulity" is past.

Frentantle, W. Australia, May ig H. C. BARNETT Colonial Surgeon

Mechanical Difículty in Growth of Plants and Animals

IN reading reports and discussions on natural science, to which I am, from great pressure of other occupation and studies, only able to give a cursory attention, I cannot find any allusion to the mechanical means by which the growth of organised creatures is produced, especially when that growth takes place in opposition to the direction of gravitation. The explanation at which I have arrived of this phenomenon may probably be known to physiologists, and may have been ac knowledged or disproved; any way I think the subject might be fairly discussed in a popular journal such as yours.

The growth of the roots of a plant and of drooping branches not being in opposition to the attraction of the earth, presents only the difficulties which arise from vital action, but the in crease of a plant in height requires also explanation as to how ihe work is done of lifting vegetable matter higher and higher; capillary attraction can bring fiuid to the summit of a tube such as the stem of a plant, but the fluid cannot overflow at the top, since in that case the matter of the tube would lift the fluid above itself; but when a tube is full of fluid, additional heat expanding this fluid would cause it to overflow at the top of the tube. As the sap contains solids in solution, from this the fluid conld deposit an additional length of tubing, in which again an additional length of the column of fluid could be absorbed, so the heat of each day would build up a higher vertical tube, and capillary attraction would account for the costir fluids produced at night or rising from the root filling the vessels to their extremities. It seems to me, therefore, that the work done in lifting vegetable matter to the apex of a plant is due to the increase of heat in the daytime; that then the watery particles are evaporated, and the solid left deposited in the form of cylindrical vessels of small bore. In animals the prostrate posture of rest allows of growth without the difficulty of resisting gravitation; it is well known that deficiency of sleep (perhaps more accurately of rest) stunts the growth of animals, and that illnesses which keep children in bed during their years of growth almost always cause a rapid increase of stature; surely this arises from the newly-formed tissues having no gravitation to overcome, and therefore developing rapidly. Probably if a child were taught to take rest in a vertical position, it would not grow tall, but develop in breadth.

The work done in increasing the stature of plants every year must be enormous ; in one summer thousands of tons of vegetable tissue must be raised through heights varying from a few inches in an oak, to twenty or thirty feet in a hopbine, and much more in a lliano, or tropical creeper. I presume in winter the cold constricts the vessels, and so prevents sap from rising, hence there is no growth at that season.

Taunton College School

II. P. KNAPTON

\section{Chemical Notation}

IN Mr. Pattison Muir's very interesting article on thermochemical investigation (NATURE, vol. $x x . p .8$, I find the following :-

"That system of notation which is now employed in chemistry, although of the greatest value, is nevertheless far from being perfect; it fails to tell anything concerning the changes in forms of energy involved in those changes of distribution of mass (matter?) which it formulates."

The author does not, however, propose any addition to the usual notation for the purpose of indicating the transformations of energy which take place in chemical transformations, yet this may be done very simply.

The symbol for water is $\mathrm{HO} \frac{1}{2}$. This states with perfect clearness the fact that a molecule of water has been formed by the combination of a molecule of hydrogen with a half molecule of oxygen, but it leaves out of account the important fact that in the act of their combination 34462 heat-units have been given out. If we call a heat-unit $\theta$, the symbol for water will then be $\mathrm{HO}_{\frac{1}{2}}-34462 \theta$; the negative sign indicating that the heat has been parted with. I propose to call such compounds thermo. negative. Products of perfect combustion, such as water and carbonic acid, are necessarily thermo-negative.

There are thermo-positive compounds, of which protoxide of nitrogen is one of the best understood. According to Fabre and Silbermann, I 54 heat-units are given out in the separation from protoxide of nitrogen of one gramme of oxygen. It is obvious that this heat must have been taken up in the formation of the protoxide. Multiplying II54 by 8 for the equivalent of oxygen, we get 9232 as the thermal equivalent of the protoxide, and we write its symbol $\mathrm{NO}+92326$.

Peroxide of hydrogen is usually written $\mathrm{HO}$, but this, from the point of view of chemical structure, is altogether wrong. Fabre and Silbermann " estimate the heat evolved during the liberation of one gramme of oxygen from peroxide of hydrogen at I363 heat-units. Multiplying by 8 as before, we have I0904 as its thermal equivalent, regarding it as a thermo-positive oxide of water, and we write its symbol

$\left(\mathrm{HO} \frac{1}{2}-34462 \theta\right)+\mathrm{O} \frac{1}{2}+\mathrm{IOgO4} \theta$.

Old Forge, Dunmurry, Co. Antrim, July 8

$$
\text { JOSEPH JOHN MURPHY }
$$

\section{Local Colour-Variation in Lizards}

Mr. Henry Hillyer Giglioli remarks (Nature, vol. xix. p. 97) that the common lizard (Podarcis muralis) constantly pre sents dark varieties on islets adjoining small islands. A similar case has come under my observation in the herpetological fauna of this country. Ameiva (cnemidophorus) vulgaris, Licht., is very common all over Venezuela, and though it varies consider ably in colour, it is, on the mainland, never black, as on the small islands of Los Roques and Orchila, which lie a short distance off our Caribbean coast. Both islands have rather extensive sandy beaches, covered with a very scanty vegetation, so that, mutatis matandis, they are, in the very words Mr. Gigliols uses when speaking of Filfa, painfully white in the gliring 